2. Poplavska O. A. Hotovnist fakhivtsiv hotelno-restorannoi spravydo profesiinoi diialnosti yak pedahohichna problema / O. A. Poplavska // Pytannia suchasnoi nauky i osvity: Pedahohika. Khmelnytskyi, 2013. - S. 25-29.

3. Riznyk V. V. Formuvannia hotovnosti maibutnikh fakhivtsiv ekonomichnykh spetsialnostei do profesiinoi diialnosti u protsesi vyvchennia spetsialnykh dystsyplin: avtoref. dys. kand. ped. nauk: 13.00 .04 / V. V. Riznyk. - Kyiv, 2010-20 s.

4. Slastenyn V.A. Pedahohyka: ynnovatsyonnaia deiatelnost / V.A.Slastenyn, L.S.Podylova. - M. : Mahystr, 1997. - 224 s.

Одержано статтю: 1.10 .2018

Прийнято до друку: 24.10.2018

УДК 378.011.3-051:373.3

DOI:10.15330/esu.14.114-120

\author{
Людмила Себало, \\ кандидат педагогічних наук, доцент \\ Національний педагогічний університет \\ імені М. П. Драгоманова (м. Київ, Україна) \\ Lyudmila Sebalo, \\ Candidate of pedagogical sciences $(\mathrm{PhD})$, \\ Associate Professor, National Dragomanov \\ Pedagogical University (Kiev, Ukraine) \\ ludok_08@ukr.net
}

\title{
ВИКОРИСТАННЯ ЗТЕМ-ТЕХНОЛОГІЙ У ПРОФЕСІЙНІЙ ПІДГОТОВЦІ МАЙБУТНІХ УЧИТЕЛІВ ПОЧАТКОВОЇ ШКОЛИ
}

\section{THE USING OF STEM-TECHNOLOGIES IN THE PROFESSIONAL TRAINING OF FUTURE PRIMARY SCHOOL TEACHERS}

Стаття присвячена сучасному напряму в освіті - актуальному питанню впроваджения STЕМ-технологій у проџес професійной підготовки майбутніх учителів початкової иколи у закладах вищої освіти. Здійснено короткий огляд нормативно-правових документів, які спрямовані на активне впроваджения STEM-технологій та STEM- освіти в Україні. Розглядаються сучасні різновиди акроніму STEM, які існують на съогодні в світі. Окреслено питання підготовки майбутніх учителів, діяльність яких не обмежується викладаниям окремого предмету, а фахівиів, які виявляють здатність до реалізачії міждисчиплінарних зв'язків. Проведено пілотне опитування серед студентів напряму підготовки "Початкова освіта" чюдо ӥхнього ставлення до окресленої проблематики. За його результатами констатовано переважання більиістю майбутніх учителів початкових класів та вчителів иодо необхідності освітніх змін, які стосуються впровадження наскрізного STEM - навчання для того, щоб оволодіти вміннями у застосуванні інноваційних ігрових технології, технологій саse-study, інтерактивних методів групового навчания; використания проблемних методик із розвитку критичного $i$ креативного мислення тоцо; створення розгалуженої системи поиуку, підтримки, навчания і супроводу талановитих студентів; створения середовица для самоосвіти та саморозвитку; залучення студентів до роботи в науково-дослідних лабораторіях у закладах вищої освіти для здобуття результативного індивідуального досвіду проектної діяльності з метою розроблення власних SMART- проектів для інтегрованих уроків природничо-математичного ијиклу, англійської мови і мистецтва, читання тоцо.

Створения таких проектів студентами буде корисним для використания під час проходження практики в закладах освіти, ио є на часі, оскільки реалізачією Концетиії "Нова українська икола" вчитель початкових класів повинен володіти технологісю роботи з LEGO-конструктором і навчати чьому учнів, а також використовувати гейміфікачію використання ігрових практик та механізмів у неігровому контексті для залучення користувачів до вирімення проблем. 
Ключові слова: професійна підготовка, STЕМ-технології, вчитель початкової иколи, навчальний прочес у закладі вищцої освіти.

The article is devoted to the modern direction in education - the actual issue of the introduction of STEM-technologies into the process of professional training of future teachers of elementary school in higher education institutions. A brief overview of regulatory documents aimed at the active implementation of STEM-technologies and STEM-education in Ukraine was conducted. The contemporary versions of the STEM acronym, which exist today in the world, are considered. The issue of preparation of future teachers whose activity is not limited to the teaching of a separate subject, and those who demonstrate the ability to implement interdisciplinary links are outlined. A study was conducted among the students on the direction of training "Primary Education" regarding their attitude to the outlined issues. According to the results of the pilot study, the overwhelming majority of future primary school teachers and teachers stated that educational changes related to the introduction of cross-STEM learning in order to master the skills in the application of innovative gaming technology, case-study technologies, interactive methods of group learning; use of problem methodologies for the development of critical and creative thinking, etc .; Creation of a comprehensive system of search, support, training and support for talented students; creation of the environment for selfeducation and self-development; attracting students to work in research laboratories in higher education institutions in order to obtain an effective individual experience of project activity in order to develop their own SMART projects for integrated lessons in the natural-mathematical cycle, English language and art, reading, etc.

The creation of such projects by the students will be useful for use during the passing of the practice in educational institutions, which is on time, since the implementation of the Concept "New Ukrainian School" elementary school teacher should have the technology of working with the LEGO designer and teach the children, as well as use the gameplay - the use of gaming practices and mechanisms in a non-gaming context to engage users in solving problems.

Key words: vocational training, STEM-technology, elementary school teacher, educational process in higher education institution.

Постановка проблеми. Загальні світові тенденції функціонування сучасного суспільства окреслюють необхідність навчання та розвитку майбутніх учителів впродовж життя, що обумовлює їхню активну самореалізацію та високий рівень конкурентоспроможності в умовах Нової української школи. Важливо, що педагоги критично оцінюють сучасний стан освіти: “Сьогодні у нас дві проблеми в навчанні. Перша - це перевантаженість предметами... I друга проблема - те, що ми даємо суто навчальний матеріал. Випускник української школи не вміє застосувати набуті знання в житті. Він, як фарширована риба, розумієте? Нібито і риба, але не плаває" [1]. Проте більшості учителів складно визначити ефективні способи й оптимальні шляхи подолання проблемних питань у шкільній практиці. Наразі затребуваними $\epsilon$ креативні вчителі, які цікавляться дитячим життям та розуміють інтереси учнів, підтримують їх у самореалізації та спонукають до дослідницької діяльності, новаторства, розвивають цілеспрямованість і творчі здібності. А сучасного школяра цікавлять робототехніка, конструювання, програмування, моделювання, 3Dпроектування, що передбачено в STEM-технологіях. Тому суттєвих змін зазнає процес та зміст підготовки майбутнього вчителя, який повинен мати: знання, уміння, володіти ключовими компетенціями з різних областей суспільних наук, інженерії, технології та математики та здатність до їх передачі своїм вихованцям. Адже майбутнє, що грунтується виключно на науці, навряд чи когось зацікавить. Вчитель 
сьогодні - це фахівець 3 реалізації ігрових і діяльнісних методів навчання у початковій школі. Тому важливі практичні навички, які формують нові уміння, підвищують професійний рівень адаптації до стрімко змінюваних умов життя суспільства, змін в освіті, науці та впровадженні в практику. У зв'язку з цим актуалізується проблема удосконалення професійної підготовки майбутніх учителів початкової школи, пошуку та впровадження STEM-технологій навчання. Зміна традиційної структури уроку сприятиме продуктивності оновленого навчального процесу, створенню необхідних умов для успішного та якісного навчання школярів в процесі інтеграції предметів.

Аналіз останніх досліджень і публікацій. Студіювання наукових розвідок останнього десятиліття засвідчує, що основним трендом у світовому освітньому просторі $\epsilon$ STEAM-технології, котрі позиціонуються ефективними способами удосконалення освітніх процесів. Загальні аспекти застосування новітніх технологій та розвитку STEM-освіти в Україні, іiі проблеми та перспективи розглядаються у працях І.П. Василашко, Н. В. Морзе, В. Д. Шарко. Методичні рекомендації щодо впровадження STEM-технологій у закладах освіти пропонуються у публікаціях Андрущенко Т.І., Буліги С.М., Бревус С.М., Величка В.Ю., Гальченко С.А., Глоби Л.С., Гуляєва К.Д., Камишини В.В., Клімової К.Я., Комової О.Б., Крутій К.Л., Лісового О.В., Ніколенка Л.Г., Норчевського Р.В., Попової М.А., Приходнюка В.В. та інших. Водночас питання щодо застосування означених інновацій у системі професійної підготовки майбутніх учителів початкової школи залишається малодослідженим.

Мета статті. Відтак у межах статті проаналізуємо проблему впровадження STEM-технологій у контексті основних підходів здобуття вищої педагогічної освіти майбутніми вчителями початкової школи.

Виклад основного матеріалу. Запровадження STEM-освіти та впровадження STEM-технологій здійснюється відповідно до законів України "Про освіту", “Про дошкільну освіту”, “Про загальну середню освіту”, “Про позашкільну освіту”, “Про професійно-технічну освіту", "Про вищу освіту", "Про наукову та науково-технічну діяльність”, “Про інноваційну діяльність”; Концепції реалізації державної політики у сфері реформування загальної середньої освіти на період до 2029 року "Нова українська школа" [1]; Концепції розвитку цифрової економіки та суспільства України на 2018-2020 роки [2]. 3 наукових джерел відомо, що акронім "STEM" вперше запропонував американський бактеріолог Р. Колвелл в 1990-х роках. Широкої популяризації означена абревіатура набула з 2000-х років. Термін STEM був введений в шкільну програму 31 класу для розвитку компетенцій учнів у науково-технічному напрямі та у сфері високих технологій. У науковому дискурсі існують різні інваріанти тлумачення акроніму. Абревіатуру STEM розшифровують так: S - science "наука", що допомагає зрозуміти навколишній світ; T - technology “технологіi”, спосіб (засіб) покращення світу, що має чутливість до соціальних змін; E - engineering "інженерія, проектування, дизайн” як спосіб створення та покращення пристроїв для вирішення реальних проблем; $\mathrm{M}$ - mathematics "математика", як спосіб опису світу "аналіз світу і реальних проблем за допомогою числа" [4]. Та є варіації: STEAM (+ A- Art “мистецтво”), STREAM (Science, Technology, Reading+WRiting Engineering, Arts, and Mathematics - акронім слів природничі науки, технологія, читання + письмо, інжиніринг, мистецтво, математика), або ж STREM (3'являється robotics - робототехніка), STEMM (+ M Medicine - медицина). А отже, це знання та уміння з дисциплін, які $є$ самими 
затребуваними в сучасному світі та $€$ складовими ключових компетентностей сучасного випускника школи. STEAM можна знайти в кожному аспекті життя. У багатьох країнах світу, як-от: Австралія, Великобританія, Ізраїль, Китай, Корея, США та ін. впроваджують програми із STEM-освіти. В Україні також адекватно сприймають цю проблему та усвідомлюють, що можуть 3'явитися такі професії, які пов'язані з біо- та нано-технологіями. Один із засновників концепції STEM-освіти Том Цу говорить, що школярі повинні обов'язково розуміти зв'язок між абстрактними науковими ідеями та їх використанням на практиці. Необхідно навчати дітей корисним навичкам та знанням, які знадобляться їм в житті, за межами лабораторій та шкільної освіти. Завдання школи - створити базу, яка допоможе і в навчанні, і в побуті, навчить вирішувати проблеми, керуючись науковим підходом. Також важливо показати і можливості застосування теоретичних знань у житті.

За результатами анкетування студентів спеціальності "Початкова освіта", в якому участь взяли 303 особи, констатуємо: 61,7 \% вважають, що зміни необхідні в освіті, зокрема в підготовці майбутнього фахівця початкової школи, разом 3 тим, $35,8 \%$ не розуміють, що саме треба змінювати. Майже 72 \% знають і чули про STEM й при розтлумаченні абревіатури виявили значний науково-пізнавальний інтерес до інновації. На питання “Чи вважаєте, що за допомогою стрімкого розвитку технологій з'являються нові професії?” ствердно відповіли майже 92 \%. На питання “Чи вважаєте ви, що в початковій школі треба запроваджувати STEM-технології або їх елементи?" - 49 \% студентів впевнені в цьому, 26\% студентів засумнівалися, 21 \% студентів вважають, що це складно для дітей та вчителів. На думку 4 \% респондентів ці технології або їх елементи частково запроваджують творчі вчителі, які вважають STEM-освіту ефективною інновацією, впровадження якої забезпечує підготовку учнів до життя на основі виконання практичних вправ та розв'язання конкретних задач. Також розділились думка студентів стосовно того, що зазначені технології допоможуть залучати батьків до навчального процесу їх дітей: “за” сказали 49\%, “ні” - 51\%. Серед складнощів застосування ідей STЕМ-освіти, більшість педагогів вказують, перш за все, недофінансування освіти, а саме, недосконалу матеріальну базу в закладах освіти (зокрема, сільські заклади освіти), недостатній рівень підготовки молодих фахівців та перепідготовки досвідчених учителів, що вже працюють в закладах освіти. Також небажання самому змінюватися. “Адже багато педагогів ще не вміють досліджувати проблеми за допомогою сучасних засобів, працювати 3 великими масивами даних, робити і презентувати висновки, спільно працювати онлайн у навчальних, соціальних та наукових проектах тощо" [1].

Наразі випускник закладу вищої освіти, вчитель початкової школи - це фахівець, який, по-перше, викладає майже всі предмети та частково інтегрує предмети, а сучасна школа потребує повної інтеграції предметів; по-друге, має базові знання, отримані зазвичай під час лекцій, а в сучасній школі - це застосування та синтез не тільки знань, а набутого досвіду, здібностей; низький (середній) рівень мислення, а потрібен - 3 високою можливістю мислити критично; може розв'язувати завдання, моделювати, а робота з проектами дається складно. Затребуваними у Новій Українській школі $\epsilon$ компетентні спеціалісти, фахівці нового формату, які конструюють зміст навчальних предметів на міждисциплінарних засадах, оскільки міждисциплінарність є синергетичним поєднанням навчальних дисциплін, взаємодії методів, інструментарію для вивчення предметів та конструювання міждисциплінарних об'єктів; інтегрують навчальні предмети відповідно до певних тем, а не окремих дисциплін. Процес інтеграції сприяє підвищенню якості навчання, підвищує 
мотивацію та пізнавальну активність учня. Питання “Що це? Як його використовувати? Як його удосконалити? Як його презентувати іншим?” - це є інтеграція науки, технологіï, проектування, математики. А згодом такий майбутній фахівець стане ще й досвідченим в галузі STEM-технологій, оскільки зможе розробляти освітні STEM - програми. Це все $є$ реальним за умови упровадження STEMтехнологій в освітній процес закладу вищої освіти та необхідного створення певних організаційно-педагогічних умов, а саме:

- запровадження наскрізного STEM - навчання для того, щоб студент як майбутній учитель, вмів упроваджувати в процес навчання в закладах освіти інноваційні ігрові технології, технології case-study, інтерактивні методи групового навчання;

- використання проблемних методик із розвитку критичного і систематичного мислення тощо;

- створення розгалуженої системи пошуку, підтримки, навчання i супроводу талановитих студентів;

- надання студентам доступу до технологій. Сьогодні, коли світ пронизаний комп'ютерними мережами, діти створюють цифровий контент, обмінюються ним, а також - веб-сайти, роблять зйомку фільмів на телефони та розробляють ігри. Все це повинен вміти робити і майбутній вчитель;

- використання STEM - технології передбачає створення такого середовища, яке дозволить студентам бути активними. В будь-якому випадку студенти займаються самоосвітою та саморозвитком, а краще запам'ятовують те, чого вони навчилися, коли вони $\epsilon$ учасниками процесу, а не пасивними спостерігачами;

- створення науково-дослідних лабораторій у закладі вищої освіти для здобуття результативного індивідуального досвіду проектної діяльності, підтримуючи наукову, технічну та інженерну складову. В цих лабораторіях студенти можуть розробляти власні SMART- проекти для інтегрованих уроків природничоматематичного циклу, англійської мови і мистецтва, читання та ін. Вивчення англійської мови відбувається одночасно із засвоєнням більшості технологій. Дитина в ігровій формі починає вивчати іноземну мову. Такі створені проекти студент може використовувати під час проходження практики в закладах освіти, а це $\epsilon$ актуальним, оскільки за Концепцією Нової української школи вчитель має вміти сам працювати 3 LEGO-конструктором та навчати цього дітей, а також використовувати гейміфікацію (e-learning) (геймміфікація ігрофікація, геймізація, від англ. gamification). Гейміфікація - це використання ігрових практик та механізмів у неігровому контексті для залучення користувачів до вирішення проблем), що є допоміжним засобом в навчальному процесі. Як зазначає М. Левин, 3 п'яти трендів освіти, наведені журналом "Форбс", - дистанційна освіта, персоналізація, гейміфікація, інтерактивні підручники, навчання через відеоігри - чотири належать до гейміфікації [3].

Цікавим $\epsilon$ те, що в початковій школі можуть бути використані не тільки конструктори "LEGO", які входять до напрямку робототехніки, а і навчальні іграшки - STEM toys. "LEGO" називають навчальним, тому що він дає дитині уявлення про навколишній світ та знайомлять із принципами його функціонування, допомагає дитині у дослідній роботі та дозволяє проводити наукові експерименти. Ігризавдання такого типу покликані сприяти не лише розвитку компетентностей учнів початкової школи, а і становленню педагога нової української школи, який здатен 
розвивати мислення, мовлення, творчість, увагу, оперативну пам'ять, ментальну (когнітивну) гнучкість та самоконтроль учнів початкової школи. LEGO - технологія дозволяє працювати в команді. “Чарівні" цеглинки здатні згуртувати, навчити взаємодіяти і доповнювати один одного. Адже складні завдання завжди краще виконувати разом. Та LEGO є надійним помічником при індивідуальних завданнях, оскільки дитині теж інколи треба давати час на те, щоб самостійно осмислити щось, обдумати. В цьому випадку LEGO розширює сферу фантазій.

Також актуальним сьогодні є вміння вчителя в навчанні дітей створювати лепбуки. Лепбук (lapbook), або як його ще називають тематична або інтерактивна папка, - це саморобна книжечка з "кишеньками", де дитина може складати на свій розсуд різноманітний матеріал до відповідної теми, конкретного предмету або інтегрувати декілька предметів. Це збір матеріалу по якійсь певній темі та заключний етап самостійної дослідницької діяльності, яку дитина виконувала у ході вивчення даної теми. Щоб заповнити цю папку, учневі потрібно буде виконати певні завдання, провести спостереження, вивчити, дослідити наданий матеріал. Дитина більш зацікавлена у навчанні, коли воно “оживає”, до нього можна торкнутись.

Створення лепбука допоможе закріпити і систематизувати вивчений матеріал, а використання матеріалу папки в подальшому дозволить швидко освіжити в пам'яті пройдені теми та закріпити вивчений матеріал.

Створення лепбука є одним з видів спільної діяльності дорослого і дітей. Тому слід відходити від традиційних форм роботи з батьками, а вчитися переконувати та залучати батьків до такої співпраці, де є взаємодія: вчитель - батьки, батьки - діти. Це носить інтерактивний характер, забезпечує кращий зворотній зв'язок.

А отже, майбутній вчитель, навчаючись у закладі вищої освіти, створює лепбуки, інтегруючи предмети, вивчає технологію виготовлення, послідовність роботи. Це: 1) тема, мета 2) складання плану, 3) наповнення лепбука. Також створені (систематизовані) лепбуки майбутніми вчителями початкової школи можуть використовуватися на практиці в закладах освіти, для організацій учнівських презентацій (наприклад, теми презентації "Планети Сонячної системи", "Мій здоровий спосіб життя", тощо) у парах, групах; для формування оцінювання в якості портфоліо; для навчання учнів початкової школи.

Заслуговують на увагу і віртуальні лабораторії, імітаційні тренажери, освітні сайти, які можуть створювати майбутні вчителі, а отже, такі майбутні фахівці створюватимуть позитивну мотивацію на опанування учнями STEM-технологіями.

Серед перерахованих вище переваг використання майбутніми вчителями STEM - технологій, зазначимо і ряд недоліків, а саме:

1. Недостатній розвиток творчих навичок, оскільки більше наголошується на технічній стороні процесу.

2. Недостатній розвиток комунікативних навичок, оскільки більше часу проводять 3 книгою. Веде до неусвідомлення ролі ефективного спілкування. Невміння усно і письмово висловлювати й тлумачити поняття, думки, почуття та емоції, факти та погляди (через слухання, говоріння, читання, письмо, застосування мультимедійних засобів). Здатність реагувати мовними засобами на повний спектр соціальних і культурних явищ - у навчанні, на роботі, вдома, у вільний час. I як наслідок, невміння розв'язувати життєві питання.

3. Якщо вчитель буде працювати тільки в цьому напрямку, то у дітей буде знижена здатність розуміти твори мистецтва, здатність формувати власні 
мистецькі смаки, самостійно виражати думки, досвід та почуття за допомогою мистецтва.

4. Недостатній руховий режим, порушення режиму. I як наслідок - отримання захворювань опорно-рухового апарату.

Висновки. Підсумовуючи все вищесказане, можна відзначити, що потреба у формуванні STEM-освітнього середовища в системі вищої освіти Україні надзвичайно актуальна. Запровадження ідей STEM-освіти у закладах вищої освіти, який $€$ перспективним напрямом, надає більше можливостей зростанню компетентісних фахівців у галузі "Початкова освіта". Та таких, які мають у порівнянні з стандартною підготовкою, технологічно вищий рівень майстерності, грунтовно розуміють суть наукових процесів в галузі, будуть здатні генерувати i реалізовувати власні ідеї та навчати цьому своїх учнів.

Вчитель сьогодні - це фахівець, що формує у дітей компетенції, які $\epsilon$ ключовими при використанні STEM-технологій: креативність, критичне мислення, науково-технічну грамотність, комунікабельність, що дає можливість в перспективі здійснювати дослідження в напрямку STEM-освіти та STEM-технологій, що на сьогоднішній день в Україні набирає обертів. Сучасний фахівець - це творчий та прогресивний вчитель, від якого, в більшій мірі, залежить яким буде освічене покоління майбутнього. Майбутній вчитель розуміє можливості та переваги STEMтехнологій в роботі з учнями початкової школи для розвитку творчості дитини, можливості використання лепбуку у роботі з батьками. Тому наступні дослідження слід виконувати в напряму взаємодії дітей та батьків із впровадження STEMтехнологій.

1. Концепція Нова українська школа. - [Електронний ресурс] - Режим доступу: https://mon.gov.ua/ua/tag/nova-ukrainska-shkola

2. Концепція розвитку цифрової економіки та суспільства України на 2018-2020 роки. [Електронний ресурс] - Режим доступу: http://zakon.rada.gov.ua/laws/show/67-2018-p

3. Левин М. Как технологии изменят образование: Пять главных трендов / М. Левин. [Електронний ресурс] - Режим доступу: http://www.forbes.ru/tehno/budushchee/82871-kaktehnologii-izmenyatobrazovanie-pyat-glavnyh-trendov

4. Шулікін Д. STEM-освіта: готувати до інновацій / Д. Шулікін // STEM- освіта в Україні: від дошкільника до компетентного випускника: матер. Всеукр. круглого столу (м. Київ, 29 червня 2015 року). - Освіта України. - 2015. - № 26. - С. 8-9.

5. Meeth L.R. Interdisciplinary Studies: Integration of Knowledge and Experience / Lois Richard Meeth // Change. - 1978. - № 10. - P. 6-9.

1. Kontseptsiya shkoly Nova-ukraska. - [Elektronnyy resurs] - Rezhim dostupa: https://mon.gov.ua/ua/tag/nova-ukrainska-shkola

2. Kontseptsiya rozvytku tsyfrovoyi ekonomiky ta suspilstva Ukrayiny na 2018-2020 roky. [Elektronnyy resurs] - Rezhym dostupu: http://zakon.rada.gov.ua/laws/show/67-2018-r

3. Levin M. Kak tekhnologiya izmenit obrazovaniye: Pyat' osnovnykh tendentsiy / M. Levin. [Elektronnyy resurs] - Rezhim dostupa: http://www.forbes.ru/tehno/budushchee/82871-kaktehnologii-izmenyatobrazovanie-pyat-glavnyh-trendov

4. Shulikin D. STEM-osvita: gouvati k innovatsii / D. Shulikin // STEM-osvita v Ukraine: $s$ doshkol'nitskoy gramotnym aspirantom: mater. Ves' kruglyy stol (m. Kiyev, 29 iyunya 2015 goda). Osvíta Ukraïni. - 2015. - № 26. - s. 8-9.

5. Meeth L.R. Interdisciplinary Studies: Integration of Knowledge and Experience / Lois Richard Meeth // Change. - 1978. - № 10. - P. 6-9. 